\title{
An Economic Analysis of Migration among the Badagas of the Nilgiris
}

\author{
P. Shanmugam* \\ Assistant Professor, Department of Economics, Bharathiar University, \\ Coimbatore -641046, India; bushanmugam@gmail.com
}

\begin{abstract}
This paper intends to analyse the migration of a single community namely the Badagas of the Nilgiris for various reasons. Earlier only a few Badagar were migrated to get employment and transfer/promotion in their jobs. Though the Badagas were stated many reasons, the root cause was the fall in the price of tea during the late 1990s. Since then these Badagas were slowly spread to the neighbouring districts viz., Coimbatore, Tirupur and Erode. Coimbatore is the adjoining district where they could get easy access for all their needs and also to contact their relations in the native. In this context, this paper tries to focus on the reasons for migration and also to analyse the determinants of migration among the Badagas by selecting two villages in north Coimbatore.
\end{abstract}

Keywords: Migration, Badagas, Determinants of Migration

\section{Introduction}

The movement of people from one place to another for taking permanent or semi permanent residence, across a political boundary is migration. Migration is taking place for so many reasons, viz., earning more money; employment opportunities and some are forced to move due to disaster or eviction by the authorities [9]. Migration is also taking place due to poor environmental conditions, lack of education, medical care and basic needs [8]. It could be revealed from the earlier studies that about 98 million people were migrated during the decade 19912001. In which, 33 million were male and 65 million were female [6]. Among the male, closer to one fourth migrated within the states while one fourth moved between the states. This indicated that mobility of Indian population has significantly increased from 1990s.

By the end of 2010, about 214 million people i.e., 3 per cent of the world's population lived out of their mother country. The migration from rural to urban areas contributed to the explosive growth of cities around the world [21]. The number of Indian-born people living outside India doubled between 1990 and 2013 i.e., from 7 million to 14 million [18]. India has the largest number of people living outside its borders during 2013 [3], i.e., 19 per cent of the total Indian population migrated internally, in which around 70 per cent were women, and marriage was the primary reason. Differently, men (12.3 million) migrated mostly for employment purpose [13]. About 56 per cent of urban male migrants move in search of employment. But in Tamil Nadu about 35.5 percent of migration was due to employment related reasons. The other major reasons for migration among Indian men were family, business, and education and most of the migrants were between 16 and 40 age group, while in Tamil Nadu it was in the age group of $35-59$ (35\%) [16]. The cities like Mumbai, Delhi, and Kolkata absorb people from other states across India [14]. The highest number of

${ }^{*}$ Author for correspondence 
migrants (1.08 lakhs) was from Tamil Nadu. The number of migrants from Tamil Nadu was nearly 19,500, which was somewhat more than that of other states. The economic reasons such as poverty, unemployment and poor wages were behind the emigration of a large number of people from Tamil Nadu [10, 20].

The Badagas are a unique community living mainly in the Nilgiris District of Tamil Nadu in South India [7]. They are also the single largest community of the Nilgiris. Badagas were traditional agriculturalists who cultivated all kinds of vegetables and cereals [2]. During the British period, tea was introduced and planted in many parts, since then tea was the major crop cultivated by the Badagas. It was no doubt that they lived a sophisticated life till the second half of 1990s. During this period the price of green tea leaves had gone down to a greater extent, which affected them extremely. A continuous fall in tea price forced them to go for other works especially in the plain districts viz., Coimbatore, Erode and Tirupur. In this connection, a study on them especially on their migration is warranted.

\subsection{Review of Literature}

Plethora of studies focused the issue of migration and its causes and consequences. In which some of the studies listed here. Rao [17] examined the migration trends that caused low population growth in the district of Srikulam. Using primary data, the author found that many rural youth are attracted to the city for education and employment because of Srikulam village depends upon agriculture. Madhavi [12] made a primary study with five hundred respondents and concluded that a majority of the migrants moved to Navi Mumbai because of either non availability of houses or very high rents in Mumbai. Another one quarter of the migrants moved to avail employment opportunities and to fetch good infrastructure facilities at Navi Mumbai. Kashish Gupta [11] pointed out that hundreds of farmer families were forced to migrate from Bundelkhand to other parts of the country in search of livelihood due to drought.

Das and Arunananda Murmu [4] found that a large magnitude of female migration linked to marriage and other associated reasons. Prakash Lansani and Honakeri [15] found that scheduled caste population in Karnataka migrated to neighboring state for their livelihood due to unemployment in their villages. Anupam Hazra [5] is of the view that lack of employment opportunities in the rural areas and better employment prospects and infrastructure facilities in the urban areas motivate people to migrate to urban areas. Vinayakam and Sekar [22] strongly advocated that the major reasons for migration in Chennai city were job (74\%), business (10\%) and marriage (6\%). Arivazhagan,
Udhayakumar and Arivazhagan [1] stated that in Vilupuram district of Tamil Nadu, more than one third of the migrants migrated due to seasonal work in the nearby villages and many of them were in the age group of 25-35 years.

\section{Statement of the Problem}

It could be observed from the studies reviewed above that the migration has a long history and it has its own impact on urbanisation and wellbeing of the migrants. Migration has been taking place for many reasons such as employment, education, marriage, etc. However, only a few studies focused on the migration of a single community for various reasons. More recently, the Badagas were moving towards south especially to Coimbatore district for many reasons. The first and foremost reason is that they were not able to manage the tea farms due to a fall in tea prices. Further, the shortage of labourers in tea plantations also forced them to leave their natives (the Nilgiris). In this context, this article makes an attempt to analyse the causes and consequences of the migration of Badagas.

\section{Objectives}

The main objectives of this paper are

1. To study the socio economic status of the migrant respondents in their destination.

2. To analyse the reason for migration and the impact of migration on households' income and expenditure.

3. To find out the factors influencing migration.

4. To identify the problems faced by respondents at migrated place.

5. To suggest policy measures to safeguard the migrants.

\section{Hypothesis}

In view of the above objectives the following hypothesis is formulated and reads as "The migration among the Badagas much influenced by the economic factors viz., asset, income, expenditure, employment etc", than the social factors viz., age, sex, marital status, type of family etc".

\section{Methodology}

The present work is based on primary data. The data were collected from 100 migrant households in Thudiyalur and N.S. Palayam villages of Coimbatore district of Tamil Nadu. A stratified random sampling technique has been used to select these households. The Badagas of the Nilgiris have 
been migrating to the adjoining districts especially to Erode and Coimbatore. In which Coimbatore comprises most of the migrant Badagas than Erode district. So, Coimbatore district was purposively selected for the present study. In the second stage, Northern part of the district was chosen based on the concentration of migrant Badaga population. In the next stage out of many villages, Thudiyalur and N.S.Palayam were purposively selected as these villages have more Badaga migrants than the other locations. In the final stage, 10 per cent the migrant Badaga households have been selected. Based on which 60 households from Thudiyalur, and 40 households from N.S.Palayam were selected for the present survey and the total sample size is 100 .

\section{Results and Discussion}

The distribution of the sample respondents according to the socio demographic characteristics is presented in Table 1. In total, majority of the respondents migrated were middle and young age groups. Among the villages, the middle age group was higher $(51.67 \%)$ in Thudiyalur village while in N.S Palayam young (52.50\%) dominated others. A vast majority of the respondents were female (61\%), which was common among the villages also. It is not misconstrued that the female respondents migrated to a larger level, it was actually the female respondents were only available at the time of interview. Invariably all the respondents from both the villages belonged to the Hindu religion. In the present survey 90 per cent of the respondents belonged to BC category which was followed by MBC 10 per cent. As per the communal classification of Tamil Nadu, Badagas, belonged to backward community. But recently, Thorayars of Nilgiris (a part of Badaga community) are notified under Most Backward community. And all the MBC respondents belonged to Thudiyalur village.

The education status of the respondents is given in Table 2. It could be noticed from the table that more than one half $(57 \%)$ of the respondents were graduates and 23 per cent of the respondents were higher secondary holders and 15 per cent of the respondents attained secondary level of education. Among the villages also graduate respondents were somewhat higher than the other levels of education in both the villages. It is surprising to state that none of the respondents were illiterates in both the villages.

Type of assets possessed by the respondents before and after migration is depicted in Table 3. There was some

Table 1. Socio Demographic Characteristics of the Respondents

\begin{tabular}{|c|c|c|c|c|}
\hline Sl. No & Particular & Thudiyalur & N.S.Palayam & Total \\
\hline \multirow[t]{4}{*}{1} & Age & & & \\
\hline & Young $(<35)$ & $\begin{array}{c}19 \\
(31.67)\end{array}$ & $\begin{array}{c}21 \\
(52.50)\end{array}$ & $\begin{array}{c}40 \\
(40)\end{array}$ \\
\hline & Middle ( $35-60)$ & $\begin{array}{c}31 \\
(51.67)\end{array}$ & $\begin{array}{c}15 \\
(37.50)\end{array}$ & $\begin{array}{c}46 \\
(46)\end{array}$ \\
\hline & Old $(>60)$ & $\begin{array}{c}10 \\
(16.67)\end{array}$ & $\begin{array}{c}4 \\
(10)\end{array}$ & $\begin{array}{c}14 \\
(14)\end{array}$ \\
\hline \multirow[t]{3}{*}{2} & Sex & & & \\
\hline & Male & $\begin{array}{c}27 \\
(45)\end{array}$ & $\begin{array}{c}12 \\
(30)\end{array}$ & $\begin{array}{c}39 \\
(39)\end{array}$ \\
\hline & Female & $\begin{array}{c}33 \\
(55)\end{array}$ & $\begin{array}{c}28 \\
(70)\end{array}$ & $\begin{array}{c}61 \\
(61)\end{array}$ \\
\hline \multirow[t]{2}{*}{3} & Religion & & & \\
\hline & Hindu & $\begin{array}{c}60 \\
(100)\end{array}$ & $\begin{array}{c}40 \\
(100)\end{array}$ & $\begin{array}{c}100 \\
(100)\end{array}$ \\
\hline \multirow[t]{4}{*}{4} & Community & & & \\
\hline & $\mathrm{BC}$ & $\begin{array}{c}50 \\
(83.33)\end{array}$ & $\begin{array}{c}40 \\
(100)\end{array}$ & $\begin{array}{c}90 \\
(90)\end{array}$ \\
\hline & $\mathrm{MBC}$ & $\begin{array}{c}10 \\
(16.67)\end{array}$ & $\begin{array}{c}0 \\
(0.00)\end{array}$ & $\begin{array}{c}10 \\
(10)\end{array}$ \\
\hline & Total & $\begin{array}{c}60 \\
(100)\end{array}$ & $\begin{array}{c}40 \\
(100)\end{array}$ & $\begin{array}{c}100 \\
(100)\end{array}$ \\
\hline
\end{tabular}

Source: Computed

Note: Figures in parentheses are percentages to the total 
Table 2. Educational Status of the Respondents

\begin{tabular}{lcccc}
\hline Sl. No & Educational Level & Thudiyalur & N.S.Palayam & Total \\
\hline 1 & Primary & 2 & 0 & 2 \\
& & $(3.33)$ & $(0.00)$ & $(2)$ \\
2 & Secondary & 10 & 5 & 15 \\
& & $(16.67)$ & $(12.50)$ & $(15)$ \\
3 & Higher Secondary & 9 & 14 & 23 \\
& & $(15)$ & $(35)$ & $(23)$ \\
4 & Graduate & 38 & 19 & 57 \\
& & $(63.33)$ & $(47.50)$ & $(57)$ \\
5 & Technical & 1 & 2 & 3 \\
& & $(1.67)$ & $(5.00)$ & $(3)$ \\
& & 60 & 40 & 100 \\
& Total & $(100)$ & $(100)$ & $(100)$ \\
\hline
\end{tabular}

Source: Computed

Note: Figures in parentheses are percentages to the total

Table 3. Asset-wise Classification of the Respondents

\begin{tabular}{|c|c|c|c|c|c|c|c|}
\hline \multirow[t]{2}{*}{ Sl. No } & \multirow[t]{2}{*}{ Asset } & \multicolumn{2}{|c|}{ Thudiyalur } & \multicolumn{2}{|c|}{ N.S. Palayam } & \multicolumn{2}{|c|}{ Total } \\
\hline & & Before & After & Before & After & Before & After \\
\hline 1 & Dry Land & $\begin{array}{c}8 \\
(13.33)\end{array}$ & $\begin{array}{c}15 \\
(25)\end{array}$ & $\begin{array}{c}7 \\
(17.50)\end{array}$ & $\begin{array}{c}10 \\
(25)\end{array}$ & $\begin{array}{c}15 \\
(15)\end{array}$ & $\begin{array}{c}25 \\
(25)\end{array}$ \\
\hline 2 & Wet land & $\begin{array}{c}38 \\
(63.33)\end{array}$ & $\begin{array}{c}36 \\
(60)\end{array}$ & $\begin{array}{c}26 \\
(65)\end{array}$ & $\begin{array}{c}22 \\
(55)\end{array}$ & $\begin{array}{c}64 \\
(64)\end{array}$ & $\begin{array}{c}58 \\
(58)\end{array}$ \\
\hline 3 & Dwelling House & $\begin{array}{c}54 \\
(90)\end{array}$ & $\begin{array}{c}36 \\
(60)\end{array}$ & $\begin{array}{c}39 \\
(97.50)\end{array}$ & $\begin{array}{c}30 \\
(75)\end{array}$ & $\begin{array}{c}93 \\
(93)\end{array}$ & $\begin{array}{c}66 \\
(66)\end{array}$ \\
\hline 4 & Television & $\begin{array}{c}55 \\
(91.67)\end{array}$ & $\begin{array}{c}46 \\
(76.67)\end{array}$ & $\begin{array}{c}40 \\
(100)\end{array}$ & $\begin{array}{c}13 \\
(32.50)\end{array}$ & $\begin{array}{c}95 \\
(95)\end{array}$ & $\begin{array}{c}59 \\
(59)\end{array}$ \\
\hline 5 & Refrigerator & $\begin{array}{c}3 \\
(5.00)\end{array}$ & $\begin{array}{c}54 \\
(90)\end{array}$ & $\begin{array}{c}2 \\
(5.00)\end{array}$ & $\begin{array}{c}39 \\
(97.50)\end{array}$ & $\begin{array}{c}59 \\
(59)\end{array}$ & $\begin{array}{c}93 \\
(93)\end{array}$ \\
\hline 6 & Washing machine & $\begin{array}{c}23 \\
(38.33)\end{array}$ & $\begin{array}{c}35 \\
(58.33)\end{array}$ & $\begin{array}{c}24 \\
(60)\end{array}$ & $\begin{array}{c}7 \\
(17.50)\end{array}$ & $\begin{array}{c}82 \\
(82)\end{array}$ & $\begin{array}{c}42 \\
(42)\end{array}$ \\
\hline 7 & Computer & $\begin{array}{c}6 \\
(10)\end{array}$ & $\begin{array}{c}15 \\
(25)\end{array}$ & $\begin{array}{c}3 \\
(7.50)\end{array}$ & $\begin{array}{c}2 \\
(5.00)\end{array}$ & $\begin{array}{c}9 \\
(9.00)\end{array}$ & $\begin{array}{c}17 \\
(17)\end{array}$ \\
\hline 8 & Telephone /Cell Phone & $\begin{array}{c}51 \\
(85)\end{array}$ & $\begin{array}{c}59 \\
(98.33)\end{array}$ & $\begin{array}{c}40 \\
(100)\end{array}$ & $\begin{array}{c}34 \\
(85)\end{array}$ & $\begin{array}{c}91 \\
(91)\end{array}$ & $\begin{array}{c}93 \\
(93)\end{array}$ \\
\hline 9 & Gas connection & $\begin{array}{c}50 \\
(83.33)\end{array}$ & $\begin{array}{c}39 \\
(65)\end{array}$ & $\begin{array}{c}40 \\
(100)\end{array}$ & $\begin{array}{c}3 \\
(7.50)\end{array}$ & $\begin{array}{c}90 \\
(90)\end{array}$ & $\begin{array}{c}42 \\
(42)\end{array}$ \\
\hline 10 & Jewels & $\begin{array}{c}57 \\
(95)\end{array}$ & $\begin{array}{c}38 \\
(63.33)\end{array}$ & $\begin{array}{c}39 \\
(97.50)\end{array}$ & $\begin{array}{c}22 \\
(55)\end{array}$ & $\begin{array}{c}96 \\
(96)\end{array}$ & $\begin{array}{c}60 \\
(60)\end{array}$ \\
\hline 11 & Consumer Durables & $\begin{array}{c}9 \\
(15)\end{array}$ & $\begin{array}{c}12 \\
(20)\end{array}$ & $\begin{array}{c}6 \\
(15)\end{array}$ & $\begin{array}{c}5 \\
(12.50)\end{array}$ & $\begin{array}{c}15 \\
(15)\end{array}$ & $\begin{array}{c}17 \\
(17)\end{array}$ \\
\hline 12 & Vehicle & $\begin{array}{c}34 \\
(56.67)\end{array}$ & $\begin{array}{c}47 \\
(78.33)\end{array}$ & $\begin{array}{c}32 \\
(80)\end{array}$ & $\begin{array}{c}19 \\
(47.50)\end{array}$ & $\begin{array}{c}66 \\
(66)\end{array}$ & $\begin{array}{c}66 \\
(66)\end{array}$ \\
\hline & Total & $\begin{array}{c}60 \\
(100)\end{array}$ & $\begin{array}{c}60 \\
(100)\end{array}$ & $\begin{array}{c}40 \\
(100)\end{array}$ & $\begin{array}{c}40 \\
(100)\end{array}$ & $\begin{array}{c}100 \\
(100)\end{array}$ & $\begin{array}{c}100 \\
(100)\end{array}$ \\
\hline
\end{tabular}


reduction in the assets of wet land, dwelling house, jewels, television, gas, etc. But some of the assets they owned were increased after migration for instance, dry land, refrigerator, consumer durables etc. Most of the respondents possessed own building in both the time periods. There was no change in the possession of vehicle before and after migration. The other assets were common and secured more or less equal percentage in both the surveyed villages at both periods. As the settled villages are plains and they belonged to hill area, made them to change their lifestyles and hence there were some changes in their asset level. Further, the land, they left at natives were wet and in the settled destination it was dry and hence a small change in land possession.

Table 4 shows the sources of income of the respondents in the surveyed villages. In total, the respondents engaged in agriculture were slightly reduced after migration. Here also one should not be misconstrued that they were engaged in agriculture in the settled place, but they have their tea plantations in their natives from which they could get income. The share of industrial works had increased from 40 per cent to 60 per cent. More than one third of the respondents gained rent from the property after migration. The share of pensioners had increased considerably after migration, while the share of services had declined drastically. It reveals that these respondents had migrated after their retirement. Among the villages, the share of service and wage had declined to a greater extent. This implied that some of the respondents have migrated after their retirement and some others have moved to higher occupation such as industrial works.

The distribution of annual income of the migrant households before and after migration is given in Table- 5

Table 4. Sources of Income of the Respondents

\begin{tabular}{llcccccc}
\hline Sl. No & Source & \multicolumn{2}{c}{ Thudiyalur } & \multicolumn{2}{c}{ N.S.Palayam } & \multicolumn{2}{c}{ Total } \\
\cline { 3 - 7 } & & Before & After & Before & After & Before & After \\
\hline 1 & Agriculture & 37 & 37 & 26 & 24 & 63 & 61 \\
& & $(61.67)$ & $(61.67)$ & $(65)$ & $(60)$ & $(63)$ & $(61)$ \\
2 & Service & 28 & 19 & 16 & 9 & 44 & 28 \\
& & $(46.67)$ & $(31.67)$ & $(40)$ & $(22.50)$ & $(44)$ & $(28)$ \\
3 & Industrial Works & 20 & 29 & 20 & 31 & 40 & 60 \\
& & $(33.33)$ & $(48.33)$ & $(50)$ & $(77.50)$ & $(40)$ & $(60)$ \\
4 & Wage & 7 & 3 & 5 & 0 & 12 & 3 \\
& & $(11.67)$ & $(5.00)$ & $(12.50)$ & $(0.00)$ & $(12)$ & $(3.00)$ \\
5 & Rent from Property & 1 & 26 & 0 & 11 & 1 & 37 \\
& & $(1.67)$ & $(43.33)$ & $(0.00)$ & $(27.50)$ & $(1.00)$ & $(37)$ \\
6 & Pensions & 1 & 22 & 0 & 12 & 1 & 34 \\
& & $(1.67)$ & $(36.67)$ & $(0.00)$ & $(30)$ & $(1.67)$ & $(34)$ \\
& \multirow{3}{*}{5} & 60 & 60 & 40 & 40 & 100 & 100 \\
& Total & $(100)$ & $(100)$ & $(100)$ & $(100)$ & $(100)$ & $(100)$ \\
\hline
\end{tabular}

Source: Computed

Note: Figures in parentheses are percentages to the total

Table 5. Distribution of Annual Income

\begin{tabular}{lccccccc}
\hline \multirow{2}{*}{ Sl. No } & Value in (Rs) & \multicolumn{2}{c}{ Thudiyalur } & \multicolumn{2}{c}{ N.S.Palayam } & \multicolumn{2}{c}{ Total } \\
\cline { 3 - 7 } & & Before & After & Before & After & Before & After \\
\hline 1 & Below 100000 & 9 & 0 & 10 & 0 & 19 & 0 \\
& $(15.00)$ & $(0.00)$ & $(25.00)$ & $(0.00)$ & $(19.00)$ & $(0.00)$ \\
2 & $100000-300000$ & 35 & 25 & 22 & 22 & 57 & 47 \\
& & $(58.33)$ & $(41.67)$ & $(55.00)$ & $(55.00)$ & $(57.00)$ & $(47.00)$ \\
3 & Above 300000 & 16 & 35 & 8 & 18 & 24 & 53 \\
& & $(26.67)$ & $(58.33)$ & $(20.00)$ & $(45.00)$ & $(24.00)$ & $(53.00)$ \\
& Total & 60 & 60 & 40 & 40 & 100 & 100 \\
& & $(100)$ & $(100)$ & $(100)$ & $(100)$ & $(100)$ & $(100)$ \\
\hline
\end{tabular}

Source: Computed

Note: Figures in parentheses are percentages to the total 
After migration the households' income had increased in the above Rs. 300000 category, while in other categories, the proportion had declined to a considerable level. It reveals that the level of income of the migrants increased to a greater extent. The village-wise analysis also reflects the same. It is also interesting to note that after migration, none of the respondents received their income at below Rs. 100000 category.

The details of saving and investment of the respondents are given in Table 6. In total, 95 per cent of the respondents have invested on jewels before migration and it was decreased to 61 per cent after migration, the same trend could be found in land and building. The respondents' investment through the insurance had increased from 28 per cent to 48 per cent. Savings in banks also increased drastically from 51 per cent to 86 per cent. In village wise analysis, the investment of the respondents of both the villages had decreased while the savings on all the heads had increased.

Table 7 depicts the year-wise migration of Badagas. It could be noticed from the table that more than one half (60\%) of the Badagas had migrated between 2000 and 2010. After 2010 the migration of Badagas was about 30 per cent. With respect to the villages also the same picture could be seen with small variation. Hence, it was accepted that the Badagas had migrated due the fall in tea price, during the late 1990s.

The source place of migration is depicted in Table 8. In total, the major source places of the Badaga migrants were Manjoor and Udhagai taluks, where tea was the major source of livelihood for most of the dwellers. Coonoor and Kothagiri taluks registered 16 per cent and only a few (3\%) Badagas had migrated from Gudalur. At the village level 47.50 per cent of the migrated respondents

Table 6. Classification of Saving and Investment of the Respondents

\begin{tabular}{llcccccc}
\hline \multirow{2}{*}{ S1. No } & Saving / Investment & \multicolumn{2}{c}{ Thudiyalur } & \multicolumn{2}{c}{ N.S.Palayam } & \multicolumn{2}{c}{ Total } \\
\cline { 3 - 8 } & & Before & After & Before & After & Before & After \\
\hline 1 & Purchase of Land & 46 & 13 & 32 & 9 & 78 & 22 \\
& & $(76.67)$ & $(21.67)$ & $(80.00)$ & $(22.50)$ & $(78.00)$ & $(22.00)$ \\
2 & \multirow{2}{*}{ Building } & 53 & 36 & 39 & 29 & 92 & 65 \\
& & $(88.33)$ & $(60.00)$ & $(97.50)$ & $(72.50)$ & $(92.00)$ & $(65.00)$ \\
3 & Saving in Banks & 35 & 54 & 16 & 32 & 51 & 86 \\
& & $(58.33)$ & $(90.00)$ & $(40.00)$ & $(80.00)$ & $(51.00)$ & $(86.00)$ \\
4 & Jewels & 57 & 39 & 38 & 22 & 95 & 61 \\
& & $(95.00)$ & $(65.00)$ & $(95.00)$ & $(55.00)$ & $(95.00)$ & $(61.00)$ \\
5 & Insurance Premium & 24 & 28 & 4 & 15 & 28 & 43 \\
& & $(40.00)$ & $(46.67)$ & $(10.00)$ & $(37.50)$ & $(28.00)$ & $(43.00)$ \\
& \multirow{4}{*}{ Total } & 60 & 60 & 40 & 40 & 100 & 100 \\
& & $(100)$ & $(100)$ & $(100)$ & $(100)$ & $(100)$ & $(100)$ \\
\hline
\end{tabular}

Source: Computed

Note: Figures in parentheses are percentages to the total

Table 7. Year-wise Migration of the Badagas

\begin{tabular}{llccc}
\hline Sl. No & Year & Thudiyalur & N.S.Palayam & Total \\
\hline 1 & Before 1990 & 3 & 0 & 3 \\
& & $(5)$ & $(0)$ & $(3)$ \\
2 & $1990-2000$ & 6 & 1 & 7 \\
& & $(10)$ & $(2.50)$ & $(7)$ \\
3 & $2000-2010$ & 36 & 24 & 60 \\
& & $(60)$ & $(60)$ & $(60)$ \\
4 & After 2010 & 15 & 15 & 30 \\
& & $(25)$ & $(37.50)$ & $(30)$ \\
& & 60 & 40 & 100 \\
& Total & $(100)$ & $(100)$ & $(100)$ \\
\hline
\end{tabular}

Source: Computed

Note: Figures in parentheses are percentages to the total 
from Udhagai were settled in N.S.Palayam and 41.67 per cent of the migrant Badagas from Manjoor were settled in Thudiyalur. Thus a group of Badagas settled earlier had invited others to settle in the same location and hence the settled place was uniform for the migrants from same source place.

Reasons for migration of the Badagas are given in Table 9. It could be observed from the table that more than 40 per cent of the respondents had migrated for employment purpose and all other reasons stated were low and ranged in between 4 and 15 per cent. In case of the surveyed villages also, employment occupied first position in both the villages. However, the proportion was somewhat high in N.S Palayam (50\%) than that of Thudiyalur (36.67\%). It could also be observed that one fifth of the respondents had migrated for study purpose in Thudiyalur village while in N.S Palayam none migrated for this purpose.

Garrett ranking technique (Table 12) was also used to rank the reasons for migration, in which employment was ranked first with the mean score of 57.5. Studies and transfer of jobs were ranked second and third respectively. The last rank was given to health with the mean score of 46.55. Thus, search for employment was the prime reason for migration of the Badagas.

Table 10 reveals the primary occupation of the Badagas before and after migration. In all, before migration, closer one third of the Badagas were agriculturalists but it was only two per cent after migration. Likewise, a considerable proportion of the respondents (20\%) were in government jobs, which was reduced to seven per cent after migration

Table 8. Source Place of Migration

\begin{tabular}{llccc}
\hline Sl. No & Taluk & Thudiyalur & N.S.Palayam & Total \\
\hline 1 & Udhagai & 12 & 19 & 31 \\
& & $(20)$ & $(47.50)$ & $(31)$ \\
2 & Manjoor & 25 & 9 & 34 \\
& & $(41.67)$ & $(22.50)$ & $(34)$ \\
3 & Coonoor & 9 & 7 & 16 \\
& & $(15)$ & $(17.50)$ & $(16)$ \\
4 & Kothagiri & 11 & 5 & 16 \\
& & $(18.33)$ & $(12.50)$ & $(16)$ \\
5 & Gudalur & 3 & 0 & 3 \\
& & $(5)$ & $(0)$ & $(3)$ \\
& Total & 60 & 40 & 100 \\
& & $(100)$ & $(100)$ & $(100)$ \\
\hline
\end{tabular}

Note: Figures in parentheses are percentages to the total

Table 9. Reasons for Migration among the Respondents

\begin{tabular}{llccc}
\hline Sl. No & Reason & Thudiyalur & N.S.Palayam & Total \\
\hline 1 & Employment & 22 & 20 & 42 \\
& & $(36.67)$ & $(50.00)$ & $(42.00)$ \\
2 & Climate & 2 & 2 & 4 \\
& & $(3.33)$ & $(5.00)$ & $(4.00)$ \\
3 & Retirement & 7 & 7 & 14 \\
& & $(11.67)$ & $(17.50)$ & $(14.00)$ \\
4 & Job Transfer & 8 & 7 & 15 \\
& & $(13.33)$ & $(17.50)$ & $(15.00)$ \\
5 & Studies & 12 & 0 & 12 \\
& & $(20.00)$ & $(0.00)$ & $(12.00)$ \\
6 & Health & 9 & 4 & 13 \\
& & $(15.00)$ & $(10.00)$ & $(13.00)$ \\
& Total & 60 & 40 & 100 \\
& & $(100)$ & $(100)$ & $(100)$ \\
\hline
\end{tabular}

Source: Computed

Note: Figures in parentheses are percentages to the total 
Table 10. Primary Occupation of the Badagas Before and After Migration

\begin{tabular}{|c|c|c|c|c|c|c|c|}
\hline \multirow[t]{2}{*}{ Sl. No } & \multirow[t]{2}{*}{ Occupation } & \multicolumn{2}{|c|}{ Thudiyalur } & \multicolumn{2}{|c|}{ N.S.Palayam } & \multicolumn{2}{|c|}{ Total } \\
\hline & & Before & After & Before & After & Before & After \\
\hline 1 & Wage labour & $\begin{array}{c}1 \\
(1.67)\end{array}$ & $\begin{array}{c}0 \\
(0)\end{array}$ & $\begin{array}{c}2 \\
(5)\end{array}$ & $\begin{array}{c}0 \\
(0)\end{array}$ & $\begin{array}{c}3 \\
(3)\end{array}$ & $\begin{array}{c}0 \\
(0)\end{array}$ \\
\hline 2 & Agriculture & $\begin{array}{c}17 \\
(28.33)\end{array}$ & $\begin{array}{c}2 \\
(3.33)\end{array}$ & $\begin{array}{c}14 \\
(35)\end{array}$ & $\begin{array}{c}0 \\
(0)\end{array}$ & $\begin{array}{c}31 \\
(31)\end{array}$ & $\begin{array}{c}2 \\
(2)\end{array}$ \\
\hline 3 & Studies & $\begin{array}{c}6 \\
(10)\end{array}$ & $\begin{array}{c}0 \\
(0)\end{array}$ & $\begin{array}{c}5 \\
(12.50)\end{array}$ & $\begin{array}{c}0 \\
(0)\end{array}$ & $\begin{array}{c}11 \\
(11)\end{array}$ & $\begin{array}{c}0 \\
(0)\end{array}$ \\
\hline 4 & Government & $\begin{array}{c}14 \\
(23.33)\end{array}$ & $\begin{array}{c}5 \\
(8.33)\end{array}$ & $\begin{array}{c}6 \\
(15)\end{array}$ & $\begin{array}{c}2 \\
(5)\end{array}$ & $\begin{array}{c}20 \\
(20)\end{array}$ & $\begin{array}{c}7 \\
(7)\end{array}$ \\
\hline 5 & Real Estate & $\begin{array}{c}1 \\
(1.67)\end{array}$ & $\begin{array}{c}1 \\
(1.67)\end{array}$ & $\begin{array}{c}1 \\
(2.50)\end{array}$ & $\begin{array}{c}0 \\
(0)\end{array}$ & $\begin{array}{c}2 \\
(2)\end{array}$ & $\begin{array}{c}1 \\
(1)\end{array}$ \\
\hline 6 & Teaching & $\begin{array}{c}8 \\
(13.33)\end{array}$ & $\begin{array}{c}4 \\
(6.67)\end{array}$ & $\begin{array}{c}3 \\
(7.50)\end{array}$ & $\begin{array}{c}2 \\
(5)\end{array}$ & $\begin{array}{c}11 \\
(11)\end{array}$ & $\begin{array}{c}6 \\
(6)\end{array}$ \\
\hline 7 & Hospital & $\begin{array}{c}2 \\
(3.33)\end{array}$ & $\begin{array}{c}2 \\
(3.33)\end{array}$ & $\begin{array}{c}0 \\
(0)\end{array}$ & $\begin{array}{c}1 \\
(2.50)\end{array}$ & $\begin{array}{c}2 \\
(2)\end{array}$ & $\begin{array}{c}3 \\
(3)\end{array}$ \\
\hline 8 & Business & $\begin{array}{c}1 \\
(1.67)\end{array}$ & $\begin{array}{c}10 \\
(16.67)\end{array}$ & $\begin{array}{c}1 \\
(2.50)\end{array}$ & $\begin{array}{c}4 \\
(10)\end{array}$ & $\begin{array}{c}2 \\
(2)\end{array}$ & $\begin{array}{c}14 \\
(14)\end{array}$ \\
\hline 9 & Army & $\begin{array}{c}5 \\
(8.33)\end{array}$ & $\begin{array}{c}0 \\
(0)\end{array}$ & $\begin{array}{c}5 \\
(12.50)\end{array}$ & $\begin{array}{c}0 \\
(0)\end{array}$ & $\begin{array}{c}10 \\
(10)\end{array}$ & $\begin{array}{c}0 \\
(0)\end{array}$ \\
\hline 10 & Engineer & $\begin{array}{c}2 \\
(3.33)\end{array}$ & $\begin{array}{c}2 \\
(3.33)\end{array}$ & $\begin{array}{c}1 \\
(2.50)\end{array}$ & $\begin{array}{c}7 \\
(17.50)\end{array}$ & $\begin{array}{c}3 \\
(3)\end{array}$ & $\begin{array}{c}9 \\
(9)\end{array}$ \\
\hline 11 & Construction & $\begin{array}{c}1 \\
(1.67)\end{array}$ & $\begin{array}{c}0 \\
(0)\end{array}$ & $\begin{array}{c}2 \\
(5)\end{array}$ & $\begin{array}{c}2 \\
(5)\end{array}$ & $\begin{array}{c}3 \\
(3)\end{array}$ & $\begin{array}{c}2 \\
(2)\end{array}$ \\
\hline 12 & Medical Rep & $\begin{array}{c}2 \\
(3.33)\end{array}$ & $\begin{array}{c}2 \\
(3.33)\end{array}$ & $\begin{array}{c}0 \\
(0)\end{array}$ & $\begin{array}{c}1 \\
(2.50)\end{array}$ & $\begin{array}{c}2 \\
(2)\end{array}$ & $\begin{array}{c}3 \\
(3)\end{array}$ \\
\hline 13 & Hotel Work & $\begin{array}{c}0 \\
(0)\end{array}$ & $\begin{array}{c}2 \\
(3.33)\end{array}$ & $\begin{array}{c}0 \\
(0)\end{array}$ & $\begin{array}{c}0 \\
(0)\end{array}$ & $\begin{array}{c}0 \\
(0)\end{array}$ & $\begin{array}{c}2 \\
(2)\end{array}$ \\
\hline 14 & Casual Work & $\begin{array}{c}0 \\
(0)\end{array}$ & $\begin{array}{c}1 \\
(1.67)\end{array}$ & $\begin{array}{c}0 \\
(0)\end{array}$ & $\begin{array}{c}0 \\
(0)\end{array}$ & $\begin{array}{c}0 \\
(0)\end{array}$ & $\begin{array}{c}1 \\
(1)\end{array}$ \\
\hline 15 & Industry & $\begin{array}{c}0 \\
(0)\end{array}$ & $\begin{array}{c}24 \\
(40)\end{array}$ & $\begin{array}{c}0 \\
(0)\end{array}$ & $\begin{array}{c}20 \\
(50.00)\end{array}$ & $\begin{array}{c}0 \\
(0)\end{array}$ & $\begin{array}{c}44 \\
(44)\end{array}$ \\
\hline 16 & Manager & $\begin{array}{c}0 \\
(0)\end{array}$ & $\begin{array}{c}3 \\
(5)\end{array}$ & $\begin{array}{c}0 \\
(0)\end{array}$ & $\begin{array}{c}1 \\
(2.50)\end{array}$ & $\begin{array}{c}0 \\
(0)\end{array}$ & $\begin{array}{c}4 \\
(4)\end{array}$ \\
\hline 17 & Manufacturing & $\begin{array}{c}0 \\
(0)\end{array}$ & $\begin{array}{c}1 \\
(1.67)\end{array}$ & $\begin{array}{c}0 \\
(0)\end{array}$ & $\begin{array}{c}0 \\
(0)\end{array}$ & $\begin{array}{c}0 \\
(0)\end{array}$ & $\begin{array}{c}1 \\
(1)\end{array}$ \\
\hline 18 & Management & $\begin{array}{c}0 \\
(0)\end{array}$ & $\begin{array}{c}1 \\
(1.67)\end{array}$ & $\begin{array}{c}0 \\
(0)\end{array}$ & $\begin{array}{c}0 \\
(0)\end{array}$ & $\begin{array}{c}0 \\
(0)\end{array}$ & $\begin{array}{c}1 \\
(1)\end{array}$ \\
\hline & Total & $\begin{array}{c}60 \\
(100)\end{array}$ & $\begin{array}{c}60 \\
(100)\end{array}$ & $\begin{array}{c}40 \\
(100)\end{array}$ & $\begin{array}{c}40 \\
(100)\end{array}$ & $\begin{array}{c}100 \\
(100)\end{array}$ & $\begin{array}{c}100 \\
(100)\end{array}$ \\
\hline
\end{tabular}

Source: Computed

Note: Figures in parentheses are percentages to the total

due to their retirement. It is interesting to note that, after migration, 44 per cent of the Badagas were engaged in industrial work, in which none of the Badagas were engaged before migration. Apart from these, after migration, the other works taken up by the Badagas were many but no one was predominant.
The problems faced by the respondents in the migrated places are given in Table 11. In total, almost all the (97\%) respondents did not face any problem. Only 3 per cent of the Badagas in Thudiyalur faced some basic problems like food and water and none of the Badagas in N.S.Palayam faced any problems. 
Table 11. Type Problems Faced by Respondents at Migrated Place

\begin{tabular}{llccc}
\hline Sl. No & Problem & Thudiyalur & N.S.Palayam & Total \\
\hline 1 & Food & 2 & 0 & 2 \\
& & $(3.33)$ & $(0.00)$ & $(2.00)$ \\
2 & Water & 1 & 0 & 1 \\
& & $(1.67)$ & $(0.00)$ & $(1.00)$ \\
3 & No problem & 57 & 40 & 97 \\
& & $(95.00)$ & $(100)$ & $(97.00)$ \\
& Total & 60 & 40 & 100 \\
& & $(100)$ & $(100)$ & $(100)$ \\
\hline \multicolumn{4}{l}{ Source: Computed } \\
Note: Figures in parentheses are percentages to the total & &
\end{tabular}

Table 12. Reasons for Migration (Garrett Ranking Technique)

\begin{tabular}{|c|c|c|c|c|c|c|c|c|c|c|c|c|}
\hline Sl. No & Factor & $\begin{array}{c}\text { Ranks } \\
\text { Scale }\end{array}$ & $\begin{array}{c}\text { I } \\
(79) \\
\end{array}$ & $\begin{array}{c}\text { II } \\
(66)\end{array}$ & $\begin{array}{c}\text { III } \\
(57)\end{array}$ & $\begin{array}{c}\text { IV } \\
(50)\end{array}$ & $\begin{array}{c}\text { V } \\
(43) \\
\end{array}$ & $\begin{array}{c}\text { VI } \\
(34) \\
\end{array}$ & $\begin{array}{r}\text { VII } \\
(21) \\
\end{array}$ & $\begin{array}{l}\text { Total } \\
\text { Score }\end{array}$ & $\begin{array}{l}\text { Mean } \\
\text { Value }\end{array}$ & Rank \\
\hline 1 & Studies & $\begin{array}{l}\mathrm{X} \\
\mathrm{FX}\end{array}$ & $\begin{array}{c}20 \\
1588\end{array}$ & $\begin{array}{c}22 \\
1452\end{array}$ & $\begin{array}{c}8 \\
456\end{array}$ & $\begin{array}{c}7 \\
350\end{array}$ & $\begin{array}{c}18 \\
774\end{array}$ & $\begin{array}{c}15 \\
510\end{array}$ & $\begin{array}{c}20 \\
420\end{array}$ & $\begin{array}{c}100 \\
5550\end{array}$ & 55.5 & II \\
\hline 2 & Climate & $\begin{array}{l}\mathrm{X} \\
\mathrm{Fx}\end{array}$ & $\begin{array}{c}8 \\
632\end{array}$ & $\begin{array}{c}4 \\
264\end{array}$ & $\begin{array}{c}20 \\
1140\end{array}$ & $\begin{array}{c}18 \\
900\end{array}$ & $\begin{array}{c}16 \\
688\end{array}$ & $\begin{array}{c}30 \\
1020\end{array}$ & $\begin{array}{c}4 \\
84\end{array}$ & $\begin{array}{c}100 \\
4728\end{array}$ & 47.28 & VI \\
\hline 3 & Employment & $\begin{array}{l}X \\
F x\end{array}$ & $\begin{array}{c}28 \\
2212\end{array}$ & $\begin{array}{c}22 \\
1452\end{array}$ & $\begin{array}{c}12 \\
684\end{array}$ & $\begin{array}{c}8 \\
400\end{array}$ & $\begin{array}{c}11 \\
473\end{array}$ & $\begin{array}{c}10 \\
340\end{array}$ & $\begin{array}{c}9 \\
189\end{array}$ & $\begin{array}{c}100 \\
5750\end{array}$ & 57.5 & I \\
\hline 4 & Job Transfer & $\begin{array}{l}X \\
F x\end{array}$ & $\begin{array}{c}24 \\
1896\end{array}$ & $\begin{array}{c}13 \\
858\end{array}$ & $\begin{array}{c}10 \\
570\end{array}$ & $\begin{array}{c}11 \\
550\end{array}$ & $\begin{array}{c}23 \\
989\end{array}$ & $\begin{array}{c}9 \\
306\end{array}$ & $\begin{array}{c}10 \\
210\end{array}$ & $\begin{array}{c}100 \\
5379\end{array}$ & 53.79 & III \\
\hline 5 & $\begin{array}{l}\text { Better } \\
\text { Employment }\end{array}$ & $\begin{array}{l}\mathrm{X} \\
\mathrm{Fx}\end{array}$ & $\begin{array}{c}16 \\
1264\end{array}$ & $\begin{array}{c}14 \\
924\end{array}$ & $\begin{array}{c}21 \\
1197\end{array}$ & $\begin{array}{c}18 \\
900\end{array}$ & $\begin{array}{c}9 \\
387\end{array}$ & $\begin{array}{c}14 \\
476\end{array}$ & $\begin{array}{c}8 \\
168\end{array}$ & $\begin{array}{c}100 \\
5316\end{array}$ & 53.16 & IV \\
\hline 6 & Health & $\begin{array}{l}\mathrm{X} \\
\mathrm{Fx}\end{array}$ & $\begin{array}{c}6 \\
474\end{array}$ & $\begin{array}{c}7 \\
462\end{array}$ & $\begin{array}{c}18 \\
1026\end{array}$ & $\begin{array}{c}15 \\
750\end{array}$ & $\begin{array}{c}22 \\
946\end{array}$ & $\begin{array}{c}25 \\
850\end{array}$ & $\begin{array}{c}7 \\
147\end{array}$ & $\begin{array}{c}100 \\
4655\end{array}$ & 46.55 & VII \\
\hline 7 & Retirement & $\begin{array}{l}X \\
F x\end{array}$ & $\begin{array}{c}18 \\
1422\end{array}$ & $\begin{array}{c}17 \\
1122\end{array}$ & $\begin{array}{c}4 \\
228\end{array}$ & $\begin{array}{c}12 \\
600\end{array}$ & $\begin{array}{c}20 \\
860\end{array}$ & $\begin{array}{c}15 \\
510\end{array}$ & $\begin{array}{c}14 \\
294\end{array}$ & $\begin{array}{c}100 \\
5036\end{array}$ & 50.36 & $\mathrm{~V}$ \\
\hline
\end{tabular}

Note: $\mathrm{X}=$ Scale value; $\mathrm{F}=$ Number of Respondents; $\mathrm{Fx}=$ Score

\section{Testing of Hypothesis}

The formulated hypothesis reads as the 'extent of migration much influenced by the economic factors rather than the social factors' was tested with a Multiple Linear Regression Model. Period of migration is taken as dependent variable and independent variables are age, sex, education, marital status, type of family etc, (social factors), asset, income, expenditure, employment, etc., (economic factors). The $\mathrm{F}$ ratio 2.522 was significant at one per cent level reveals that the overall model was good. The regression co-efficients of marital status (-1.791) and earning members (-1.782) were negatively significant at 10 per cent level denoting that they were negatively influenced the migration. The co-efficient of type of family $(-2.262)$ was negative and significant at 5 per cent level and employment (-2.809), saving and investment (3.086) were significant at 1 per cent level. The increase in saving and investment also motivated the Badagas to migrate at a larger level. Education did not influence the Badagas to migrate from their natives as it was not significant even at 10 per cent level. The R2 0.653 was explained by the predictors by 65 per cent. Thus, both economic and social factors together forced the Badagas to migrate from their natives and hence the hypothesis has partially been validated.

\section{Summary of Findings}

The present study found that more than 40 per cent of the migrant respondents were middle and young age groups. All the respondents belonged to Hindu religion, in which 90 per cent belonged to Backward Community. More than one half $(57 \%)$ of the migrants were graduates in both the villages. Most of the migrants were married and lived in 
Table 13. Determinants of Migration - Multiple Regression

\begin{tabular}{llccc} 
Model & & & & \\
\hline SI. No & Independent Variable & Beta & $\mathrm{t}$ & Sig \\
\hline 1 & (Constant) & 10.68 & 2.698 & 0.008 \\
2 & Age & .011 & .105 & .917 \\
3 & Sex & .099 & .924 & .358 \\
5 & Education & -.056 & -0.088 & -0.930 \\
4 & Marital Status & -.179 & -1.791 & $.077^{* *}$ \\
5 & Type of Family & -.232 & -2.262 & $.026^{*}$ \\
6 & Family Size & .078 & .805 & .423 \\
7 & Earning Members & -.189 & -1.782 & $.078^{* *}$ \\
8 & Assets & -.134 & -1.267 & .209 \\
9 & Annual Income & .017 & .159 & .874 \\
10 & Expenditure & .119 & 1.171 & .245 \\
11 & Saving and Investment & .334 & 3.086 & $.003^{*}$ \\
12 & Employment & -.276 & -2.809 & $.006^{*}$ \\
13 & Health & .048 & .490 & .625 \\
& F & $2.522^{*}$ & & \\
& R & $.808^{\mathrm{a}}$ & & \\
\hline & R & .653 & & \\
\hline
\end{tabular}

Note: * Significant at $1 \%$ Level ${ }^{* *}$ Significant at $5 \%$ Level ${ }^{* * *}$ Significant at $10 \%$ Level

nuclear type of family. Many migrants were living in their own concrete houses.

Most of the respondents had own building both before and after migration. But after migration many of them had lost their assets. However, the assets value was on a rise and the value of assets was between Rs.500000 - Rs.1000000. After migration, apart from agriculture, industrial work dominated other woks in the study villages. The level of income increased to a greater extent (Above Rs.300000). The investment declined after migration but the saving level increased.

The migration of the Badagas took place during 2000-2010 to a larger level. Among the source places, Manjoor and Udhagai taluks of the Nilgiris dominated other places, and many were settled in the semi urban area of Coimbatore. The major reason for migration was employment while education also caused to a considerable extent. Almost all the migrants did not face any problem after migration.

\section{Conclusion}

The present study concludes that a large level migration took place doing 2000-2010, in which many of the Badagas belonged to Manjoor and Udhagai taluks where tea cultivation was dominant and hence, the fall in tea price forced them to migrate. The major reason for migration was employment and industrial work was the primary occupation for many migrants in the destination place. Further higher studies also caused to migrate the Badagas to a considerable extent. After migration most of the migrants did not face any severe problem in the destination except food and hence they feel free in their new natives. Further, a reasonable price for tea, the establishment of small scale and cottage industries and higher educational institutions in the Nilgiris may reduce the migration of Badagas in the near future.

\section{References}

1. Arivazhagan R., Udhayakumar A, Arivazhagan V. "Rural Labour Migration: A Case Study in Villupuram District of Tamil Nadu", International Journal of Management And Development Studies, vol. 3(7), Jul. 2014. ISSN (Online): 2320-0685 21 Available: www.ijmds.com.

2. Balasubramaiyam B. "The History of Badagas - Adapted from the Book - Paame" Breeks. "The History of Badagas", Dec. 13, 2011.

3. Inkpen C. 7 Facts about World Migration, Fact Tank, Sep. 2, 2014.

4. Das., Murmu A. "Female Migration to Mega Cities of India", Journal of history and Social Sciences, vol. 1(1), p. 1-9, 2010.

HuSS: International Journal of Research in Humanities and Social Sciences 
5. Anupam H. "Rural India: Still Floating towards Cities", Kurukshetra, vol. 60(4), p. 3-5, 2012.

6. Available: http://knowledge.allianz.com/?454/indias-massive-migration-crisis.

7. Available: http://www.indiantravelportal.com/tamil-nadu/ tribes/badagas.html,

8. Available: http://www.usingenglish.com/forum/editingwriting-topics/66380-reasons-migration-essay.html

9. Human Migration Guide (K-2), National Geographic Society, Vol. 1, 2005.

10. Jothy K., Kalaiselvi S. "Patterns of Internal Migration: An Analysis Using Census Data of Tamilnadu”, International Journal of Current Research, vol. 3(1), p. 89-96, 2011.

11. Gupta K. "Drought forces Bundelkhand Farmers to Migrate". News from NDTV. Aug 17, 2009.

12. Madhavi. "Urbanisation and Migration Patterns in Navi Mumbai", Southern Economist, vol. 47(14), p. 11-13, 2008.

13. Migration: A World on the Move, "Commission on Population Development 2013", New trends in Migration: Demographic aspects North Lawn Building.

14. Neetha N. "Making of Female Breadwinners- Migration and Social Networking of Women Domestics in Delhi", Economic Political Weekly, vol. 29(17), p. 1681-1688, 2004.
15. Prakash L., Honakeri. "Inter-state Migrant Workers in Kerala: An Analysis of the Socio-Economic Background", Journal of the Indian Institute of Economics, p. 47-54, 2012.

16. Abbas R, Varma D. Internal Labor Migration in India Raises Integration Challenges for Migrants, Mar 3, 2014.

17. Rao., Appa. Rural Out- Migrants in a Low Population Growth Setting, Census 2001 and Human development in India, New Delhi: Serials publications, 2004.

18. Dwivedi R. "Migration: An Overview and Relevant Issues", Amity School or Rural Management, vol. 8(2), p. 25-33, 2012.

19. Murugan S., Lakshmi A. "Rural Development and Migrant Fishermen in Tamilnadu", Kurukshetra, vol. 59(2), p. 30-33, 2010.

20. Sushanta., Banerjee., Jayachandran., Roy. "Has Emigration Influenced Kerala's Living Standards? A Micro Level Investigation", Economic Political Weekly, vol. 26(32), p. 1755-1765, 2002.

21. UNDP Forty-Sixth Session, "Linking Population, Poverty and Development", 22-26 Apr 2013.

22. Vinayakam K., Sekar S.P. "Rural To Urban Migration in an Indian Metropolis: Case Study Chennai City", IOSR JHSS, vol. 6(3), p. 32-35, 2013. 